\title{
RESPONSE OF WINTER RAPE (Brassica napus L. ssp. oleifera Metzg., Sinsk) TO FOLIAR FERTILIZATION AND DIFFERENT SEEDING RATES
}

\author{
Cezary A. Kwiatkowski \\ Department of Herbology and Plant Cultivation Techniques, University of Life Sciences \\ Akademicka 13, 20-950 Lublin, Poland \\ e-mail: czarkw@poczta.onet.pl
}

Received: 13.01.2012

\section{Abstract}

A field experiment in growing winter rape was carried out during the period 2009-2011 in a family farm (owned by Mr. M. Bednarczyk) located in Jaroszewice (Lublin region), on podzolic soil. Plant biometric features as well as yield and seed qualitative parameters (oil, protein and glucosinolate content) were evaluated depending on the following rates of soil NPK fertilizers and on foliar fertilization (autumn spraying with the fertilizer solution): $100 \%$ and $75 \%$ of NPK as well as urea + nickel chelate $+\mathrm{MgSO}_{4} \mathrm{H}_{2} \mathrm{O} ; 100 \%$ and $75 \%$ of NPK as well as urea + Plonvit $\mathrm{R}+\mathrm{MgSO}_{4} \mathrm{H}_{2} \mathrm{O}$ ). Plots without foliar fertilization (only $100 \%$ of NPK) were the control treatment. The other experimental factor was the seeding rate $\left(2.5 \mathrm{~kg} \times \mathrm{ha}^{-1}-30 \mathrm{~cm}\right.$ row spacing; $4 \mathrm{~kg} \times \mathrm{ha}^{-1}-18 \mathrm{~cm}$ row spacing). Foliar spraying was done once in the autumn in the second decade of October.

Tillage as well as mechanical and chemical control of agricultural pests in the plantation were typical for this plant species and consistent with the recommendations for winter rape protection.

A hypothesis was made that the application of foliar fertilizers would have a beneficial effect on winter rape productivity, at the same time maintaining the high quality of raw material. It was also assumed that a reduction in the seeding rate of winter oilseed rape would result in reduced plant lodging and an increased number of siliques per plant; as a consequence, seed and oil productivity would be at a level not lower than that obtained at the higher seeding rate.

The present study has proved that foliar fertilization of winter oilseed rape in the autumn period contributes to improved plant winter hardiness and increased productivity. The application of foliar fertilizers also enables the rates of basic mineral NPK fertilizers to be reduced by $25 \%$ without detriment to seed yield. Foliar fertilizers have been found to have a weaker effect on changing the chemical composition of rapeseed. The study has shown that, from the productive point of view, it is

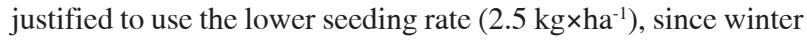
rape yield (seed and oil yield) did not significantly differ from that found in the case of the higher seeding rate $\left(4.0 \mathrm{~kg} \times \mathrm{ha}^{-1}\right)$.
Key words: winter rape, foliar fertilization, seeding rate, seed yield, nutrients, glucosinolates

\section{INTRODUCTION}

Winter rape (Brassica napus L. ssp. oleifera Metzg., Sinsk) is a plant with high nutritional requirements and it responses with a significant increase in seed yield both to soil and foliar fertilizers. This applies not only to nitrogen, potassium and magnesium, but also to other mineral nutrients (sulphur, boron). The highest nutrient uptake occurs during the intensive growth of above-ground biomass, 3-4 weeks before flowering, and subsequently during the period of silique and seed formation $(\mathrm{Czub}$ a et al. 1995; S zew c zuk, 2003). During this time, nutritional requirements for these nutrients can be met by applying foliar fertilization (P a i s, 1983; $\mathrm{H}$ a r a s i m and Fili pe k, 2009). Properly balanced fertilization affects the quality of yield and is an element enhancing winter hardiness of winter rape, in particular providing good magnesium supply to plants $(\mathrm{C} \mathrm{z} \mathrm{u} \mathrm{b} \mathrm{a} \mathrm{et}$ al. 1995). Nickel was included in micronutrients relatively recently - in 1991. The effect of its deficiency has been studied in many crop plants. However, the needs to make up Ni deficiency under field conditions are not known (Gerendás and $\mathrm{S}$ a t te $1 \mathrm{macher}$, 1997). Some compound foliar fertilizers, for example Plonvit $\mathrm{R}$, contain a whole range of elements necessary for plants (N, Mg, S, Mn, Fe, Zn, Cu, B, Ti, Mo, Na) (S z e w c z u k, 2003).

On the other hand, environmental protection considerations speak in favour of reducing, if it is rationally possible, rates of mineral fertilizers applied to crop fields every year. As shown by some studies ( $\mathrm{No}$ - 
worolnik, 1996; Chrzanowska-Drożdż, 2001; B rzozowska et al. 2008), such a measure does not always mean decreased productivity of the crop plant. Comprehensive fertilization of winter oilseed rape (soil and foliar mineral fertilization) also entails certain risks leading to excessive vegetative growth of plants, reduced silique set, and higher susceptibility to lodging. Observations based on farming practice confirm that these phenomena may occur in particular in a situation where there is a too dense oilseed rape crop. It seems that such a situation can be prevented by applying a reduced seeding rate of winter rape, which is confirmed by the study of Budzyn ski (2006). New cultivars of this plant are characterized by high germination ability and they produce a large number of branches. With a lower seeding rate, these traits can be fully utilized, since the number of evenly arranged siliques on the plant increases.

The above arguments allowed a hypothesis to be formed that the application of foliar fertilizers would have a beneficial effect on winter rape productivity, at the same time maintaining the high quality of raw material, even if the rates of soil-applied mineral NPK fertilizers are reduced by $1 / 4$. It was also assumed that a reduction in the seeding rate of winter rape would result in reduced plant lodging and an increased number of siliques per plant; as a consequence, seed and oil productivity would be at a level not lower than that obtained at the higher seeding rate. The positive results of such measures would also be economically justified.

The aim of the present study was to evaluate plant winter hardiness and lodging, biometric features, qualitative parameters and yield of winter rape under the conditions of application of foliar fertilizers in combination with two rates of mineral NPK fertilizers and different seeding rates.

\section{MATERIALS AND METHODS}

A field experiment in growing winter rape was carried out during the period 2009-2011 in a family farm (owned by Mr. M. Bednarczyk) located in Jaroszewice (Lublin region) on podzolic soil, classified as soil class III a. The experiment was set up as a split-plot design with 4 replicates. The area of a single plot was $27 \mathrm{~m}^{2}$. Spring barley was the forecrop for winter rape (the double-low hybrid cultivar 'Kronos'). factors:

The experimental design included the following

I. Rates of soil-applied NPK fertilizers and foliar-applied fertilizers:

A $-100 \%$ of the NPK rate, without foliar fertilization (control treatment);

B $-100 \%$ of the NPK rate and autumn spraying with the solution:

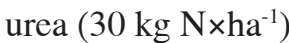

+ nickel chelate $\left(2 \mathrm{dm}^{3} \times \mathrm{ha}^{-1}\right)$

$+\mathrm{MgSO}_{4} \mathrm{H}_{2} \mathrm{O}\left(7.5 \mathrm{~kg} \times \mathrm{ha}^{-1}\right)$;

$\mathrm{C}-75 \%$ of the NPK rate and autumn spray-

ing with the solution:

urea (30 kg N×ha-1)

+ nickel chelate $\left(2 \mathrm{dm}^{3} \times \mathrm{ha}^{-1}\right)$

$+\mathrm{MgSO}_{4} \mathrm{H}_{2} \mathrm{O}\left(7.5 \mathrm{~kg} \times \mathrm{ha}^{-1}\right)$;

D $-100 \%$ of the NPK rate and autumn spraying with the solution:

urea $\left(30{\left.\mathrm{~kg} \mathrm{~N} \times \mathrm{ha}^{-1}\right)}^{-}\right.$

+ Plonvit R $\left(2.0 \mathrm{dm}^{3} \times \mathrm{ha}^{-1}\right)$

$+\mathrm{MgSO}_{4} \mathrm{H}_{2} \mathrm{O}\left(7.5 \mathrm{~kg} \times \mathrm{ha}^{-1}\right)$;

$\mathrm{E}-75 \%$ of the NPK rate and autumn spray-

ing with the solution:

urea $\left(30 \mathrm{~kg} \mathrm{~N} \times \mathrm{ha}^{-1}\right)$

+ Plonvit R $\left(2.0 \mathrm{dm}^{3} \times \mathrm{ha}^{-1}\right)$

$+\mathrm{MgSO}_{4} \mathrm{H}_{2} \mathrm{O}\left(7.5 \mathrm{~kg} \times \mathrm{ha}^{-1}\right)$.

\section{Seeding rate:}

1. 70 plants per $1 \mathrm{~m}^{2}(18 \mathrm{~cm}$ row spacing, seeding rate $\left.-4.0 \mathrm{~kg} \times \mathrm{ha}^{-1}\right)$;

2. 40 plants per $1 \mathrm{~m}^{2}(30 \mathrm{~cm}$ row spacing, seeding rate $\left.-2.5 \mathrm{~kg} \times \mathrm{ha}^{-1}\right)$.

The foliar fertilizers were applied once in the second decade of October. The concentrations of the solutions were as follows: urea $10 \%$, magnesium sulphate monohydrate $2.5 \%$, nickel chelate (EDTA-Ni) $5 \mathrm{~g} \mathrm{Ni} \mathrm{dm}^{-3}$, Plonvit $\mathrm{R}-0.67 \%$.

Tillage as well as mechanical and chemical control of agricultural pests in the plantation were typical for this plant species and consistent with the recommendations for winter rape protection.

Before sowing (in the third decade of August), the following amounts of nutrients were applied on a per hectare basis in the treatment combination with $100 \%$ of NPK (treatments A, B, D): $50 \mathrm{~kg} \mathrm{~N}$ (in the form of ammonium nitrate), $30 \mathrm{~kg} \mathrm{P}$ (granulated triple superphosphate), and $150 \mathrm{~kg} \mathrm{~K}$ (potassium salt). In the treatment combination with $75 \%$ of NPK (treatments $\mathrm{C}$ and $\mathrm{E}$ ), the following amounts were applied on a per hectare basis, respectively: $37.5 \mathrm{~kg} \mathrm{~N}, 22.5 \mathrm{~kg} \mathrm{P}$, and $112.5 \mathrm{~kg} \mathrm{~K}$. In early spring, when plant growth started, ammonium nitrate was used at an amount of $100 \mathrm{~kg} \mathrm{~N} \times \mathrm{ha}^{-1}$ (treatments A, B, D) and $75 \mathrm{~kg} \mathrm{~N} \times \mathrm{ha}^{-1}$ (treatments $\mathrm{C}$ and $\mathrm{E}$ ). The $100 \%$ rates of phosphorus and potassium fertilizers were determined on the basis of the nutritional requirements of oilseed rape and nutrient availability in the soil, which showed a medium content of P (61 mg per $1 \mathrm{~kg}$ of soil) and $\mathrm{Mg}(55 \mathrm{mg})$ as well as a low content of $\mathrm{K}(83 \mathrm{mg})$ in the $0-20 \mathrm{~cm}$ soil layer.

In the autumn and spring, plant density in pcs. $\times \mathrm{m}^{-2}$ was calculated for the individual treatments. Before harvest, the following yield components were 
determined on the basis of 30 plants randomly selected from each treatment: number of siliques per plant, number of seeds per silique on the main stem and on axillary branches as well as 1000 seed weight. Plant lodging was determined several days before harvest, using a 9-point scale. Seeds were harvested in the 3rd decade of July. After seeds were dried, seed yield was determined on a per hectare basis and seed samples were taken for laboratory analysis. Crude oil content in rapeseed was determined by the Soxhlet method, total protein content by the Kjeldahl method, while glucosinolate content by gas chromatography of desulfo-glucosinolates.

The results of the study were subjected to statistical analysis (analysis of variance using Statgraphic 5.0 software), whereas significant differences were evaluated by Tukey's test at $=0.05$.

\section{RESULTS AND DISCUSSION}

The weather in individual years of winter rape growth was generally favourable for winter survival of plants (Table 1), as crop losses were 4.6-10.9\% on average for the study period, irrespective of the experimental factors. Different seeding rates had practically no effect on the trait in question. But winter survival of oilseed rape plants significantly depended on the type of fertilization. Compared to the control treatment, the lowest crop losses were recorded in the treatment with foliar application of the solution (urea + Plonvit R + magnesium sulphate), irrespective of the rate of mineral NPK fertilizers (treatments D and E). Treatment B, in which nickel chelate was a component of the foliar solution, was also found to have better winter survival of rape plants relative to the control plots. Treatment $\mathrm{C}$ showed lower winter survival of plants (statistically significant in relation to treatment D). To sum up, it should be however noted that all foliar fertilizers showed a beneficial influence on winter survival of rape oilseed plants. This is reflected in the results of the study of C z u b a et al. (1995). These authors indicate the positive effect of foliar-applied magnesium sulphate which is supplied to plants in the autumn.

The reduction in the seeding rate of winter rape from 70 to 40 plants per $1 \mathrm{~m}^{2}$ had a significant effect on reducing plant lodging (by 0.8 percentage point) (Table 2). Statistically proven lower lodging (by 1.0-1.4 pp) was found in treatments B, D and E in relation to that in treatment $\mathrm{A}$ (without foliar fertilization).

The application of different seeding rates of winter rape had practically no effect on density of siliques on the plant (Table 3). But the foliar fertilizers generally had a beneficial influence on the trait in question. Compared to the control treatment (A), a significantly higher number of siliques per plant was found in treatments $\mathrm{B}$ and $\mathrm{C}$ where the fertilizer solution (urea + nickel chelate + magnesium sulphate) was foliar applied, irrespective of the level of soil NPK fertilization.

The study showed that seeding rate did not significantly differentiate the number of seeds per silique on the main stem of winter rape (Table 4). Nevertheless, the higher seeding rate promoted a higher number of seeds per silique. In most cases (treatments B, C and D), the applied variants of foliar fertilization showed a proven effect on increasing the number of seeds per silique on the main stem by $8-12 \%$ compared to that found in the control treatment. Such a correlation was not found for treatment $\mathrm{E}$.

In the case of axillary branches of winter rape, the average number of seeds per silique did not show any significant change under the influence of the seeding rate (Table 5). In the treatments with the reduced seeding rate, a trend to produce a higher number of seeds per silique was observed. All the treatments with foliar application of the fertilizer solution, irrespective of soil NPK fertilization, contributed to a significant increase in the number of seeds per silique on the axillary branch, on average by $21-28 \%$.

The reduction in the seeding rate of winter rape from 4.0 to $2.5 \mathrm{~kg} \times \mathrm{ha}^{-1}$ (40 plants per $1 \mathrm{~m}^{2}$ ) produced a trend towards a larger size of harvested seeds as expressed by 1000 seed weight (Table 6). The solutions of the foliar fertilizers applied during the autumn period had a beneficial effect on seed size. Compared to the control treatment, there were statistically significant differences only in the case of treatment B (100\% of the NPK rate and foliar fertilization with the solution: urea + nickel chelate + magnesium sulphate).

The differences in the seeding rate of winter rape (plant density 70 and 40 plants per $1 \mathrm{~m}^{2}$ ) did not have a significant influence on yield of this plant (Table 7). Therefore, the results of the present study make an argument for a reduction in the seeding rate of winter rape. Regardless of the type of fertilization, the difference in winter rape productivity between the

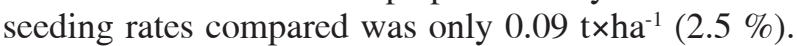
The statistical analysis confirmed the great usefulness of the solution: urea + nickel chelate + magnesium sulphate, in foliar fertilization. The increase in winter rape yield under the influence of this solution, compared to the yield obtained in the control treatment (A), was on average $0.46 \mathrm{t} \times \mathrm{ha}^{-1}(12 \%)$ and $0.54 \mathrm{t} \times \mathrm{ha}^{-1}(14 \%)$ for treatments B and C, respectively. In spite of the absence of significant differences, ca. $6 \%$ higher productivity was also recorded in treatments $\mathrm{D}$ and $\mathrm{E}$.

In the experiment of $\mathrm{Harasim}$ and Filipek(2009), the micronutrient fertilizer Plonwit $\mathrm{R}$ did not increase spring oilseed rape yield. One of the possible reasons was medium to high availability of 
micronutrients ( $\mathrm{Fe}, \mathrm{Mn}, \mathrm{Zn}, \mathrm{Cu}$ ) in the soil, which was probably sufficient to meet the fertilization requirements of the plants. The above-mentioned authors obtained the highest yield of spring rapeseed, similarly as in the case of winter oilseed rape in the present study, from the treatments where urea was foliar applied in combination with Ni chelate. In turn, Jaskulski (2004) proved that foliar application of the fertilizer "Sonata rzepak" (Mg, S, B, Mn, Zn, Cu, Fe, Mo, Co) had an effect on increasing winter rapeseed yield in the range of $110-260 \mathrm{~kg} \times \mathrm{ha}^{-1}$. B arłóg and Potarzycki (2000) recorded a significant increase in winter rapeseed and oil yield as a result of foliar fertilization with magnesium. On the other hand, Fig a s (2009) found a significant increase in rapeseed yield under the influence of soil-applied sulphur fertilization. Nevertheless, this author notes that the additional application of magnesium and boron did not significantly increase the effectiveness of sulphur fertilization of oilseed rape. S z e w c z u k (2003) argues that foliar fertilizers applied once in the autumn beneficially affect winter survival of winter rape plants and, as a consequence, they promote their higher productivity by about $11 \%$. This resulted from an increase in the number of siliques and 1000 seed weight as well as from a higher number of siliques obtained from axillary branches. $\mathrm{P}$ a i s (1983), Sienkiewicz-Cholewa and Gembarzew ski (1997) as well as Szu lc et al. (2003) indicate the yield-increasing effect of foliar fertilization of oilseed rape both in autumn and spring time.

In the opinion of some authors (P a is , 1983; Szewczuk, 2003; Harasim and Filipek, 2009), fertilizers that are characterized by a relatively high content of magnesium and boron as well as of zinc, copper and molybdenum deserve special attention among foliar fertilizers recommended for oilseed rape. Titanium is also a very important component, since it stimulates different biochemical processes taking place in the plant. Nickel is also an element that is very useful for plant fertilization, which is confirmed by the results of the present study on winter oilseed rape. M a h l e r (2004) explains this by the fact of reduced industrial emissions and agriculture intensification which promote increasingly greater nickel impoverishment of soils.

The results of the present study prove that the reduced density of winter rape plants, in particular in the case of application of foliar fertilizers, does not have an effect on reducing productivity of this plant. B u d z y n s ki (2006) reports that at a seeding rate of $2.5-3 \mathrm{~kg}$ of rapeseed per 1 ha ( 40 plants per $1 \mathrm{~m}^{2}$ ), instead of $3.5-4 \mathrm{~kg}\left(50-60\right.$ plants per $\left.1 \mathrm{~m}^{2}\right)$, the purchase cost of seed material is lower by about $20 \%$. The study of this author also shows that plant density for winter rape hybrid cultivars ranging from 35 to 45 plants per
$1 \mathrm{~m}^{2}$ - depending on the cultivar - is entirely sufficient to obtain maximum seed yield. Winter oilseed rape responds badly to too high plant density and does not manifest its yield potential under such conditions. This is particularly important in the case of hybrid varieties (K o r b it z, 2003). In the opinion of W a k k o w s k i (2001), the optimal number of plants per $1 \mathrm{~m}^{2}$ of an oilseed rape field should be $60-80$ plants under average habitat conditions and 50-60 plants under more favourable conditions. S krz y p z a k (2006) notes that, due to a very long growing period of winter oilseed rape, plants become thinned out in the crop as a result of winterkill or crop waterlogging as a consequence of the formation of meltwater or rainwater pools. Therefore, the density of oilseed rape plants after the winter period generally decreases on average by 10-17\% (B u dzyński, 2006). The present study shows that winter rape crop loss after the winter period was lower and averaged 5-10\%. This probably resulted from high winter hardiness of the cultivar 'Krosno' (COBORU, 2009) as well as from the application of foliar fertilizers contributing to greater plant resistance (S z e w c z u k, 2003).

The reduced seeding rate did not have a negative effect on seed oil content. On the contrary, a trend was observed towards a slight increase in the content of this component in seed dry weight (Table 8). Irrespective of the seeding rate used, the applied foliar fertilizers had an effect on increasing seed oil content by $1.6 \%$ (B) $-2.9 \%$ (E) of dry weight compared to that found in the control treatment. In the case of treatment E (75\% of the NPK rate and foliar fertilization with the solution: urea + Plonvit $\mathrm{R}+$ magnesium sulphate), this was a statistically significant difference.

The obtained results show distinct differences in oil yield per unit area under the influence of fertilization applied. In the control treatment $(\mathrm{A}$ - without foliar fertilization), oil yield per 1 ha of the winter rape crop was on average $1375 \mathrm{~kg}$. In treatment B $(100 \%$ of NPK and foliar fertilization with the solution: urea + nickel chelate + magnesium sulphate) and $\mathrm{C}(75 \%$ of NPK and the solution: urea + nickel chelate + magnesium sulphate), oil yield was $1627 \mathrm{~kg}$ and $1671 \mathrm{~kg}$, respectively. Slightly lower oil yield was found in the case of foliar fertilization with the solution of urea and magnesium sulphate with the addition of the fertilizer Plonvit R (treatments D and E): $1556 \mathrm{~kg}$ and $1561 \mathrm{~kg}$, respectively. The seeding rate of winter rape did not affect oil yield per unit area. Irrespective of the type of fertilization, the average oil yield per 1 ha in the treatments with plant density of 40 plants per $1 \mathrm{~m}^{2}$ was $1543 \mathrm{~kg}$, while in the case of plant density of 70 plants per $1 \mathrm{~m}^{2}-1574 \mathrm{~kg}$ (higher only by $2 \%$ ).

Protein content in winter rapeseed was not significantly differentiated under the influence of the 
experimental factors tested (Table 9). A trend towards a higher content of this component can only be noted under the influence of application of foliar fertilizers (in particular in the combination with the recommended $100 \%$ rate of soil-applied NPK fertilizers).

Different seeding rates of winter rape did not have a major effect on glucosinolate content in seeds of this plant. However, the content of the component in question was significantly dependent on the applied type of fertilization (Table 10). In the treatments in which Ni chelate was applied together with urea and magnesium sulphate (treatments B and C), a significant decrease in the content of alkenyl glucosinolates (harmful) was recorded compared to those found in the other treatments. The content of indolic glucosinolates under the conditions of treatments $\mathrm{B}$ and $\mathrm{C}$ was significantly lower only in relation to that found in the control treatment and in treatment D (100\% of NPK and Plonwit R + urea and magnesium sulphate). The most beneficial (lowest) total glucosinolate content in rapeseed was found in treatment $\mathrm{C}$ where nickel chelate was used with the rate of soil-applied NPK fertilizers reduced by $25 \%$ (significantly lower compared to treatments A, D and E). In the study of $\mathrm{S} \mathrm{zulc}$ et al. (2003), foliar sulphur fertilization of oilseed rape contributed to a lower glucosinolate content compared to the treatments where sulphur was not applied.

The results of this study show that seed oil content was in the range of $41.4-44.7 \%$. In the opinion of M a r k u s (1999), oil content at a level of 40.7-44.5\% is considered to be average. Ty s et al. (2006) note that the level of seed oil content is not a permanent parameter for a given cultivar, but it changes both during maturation and when the plant has reached full maturity. In the experiment of $\mathrm{H}$ aras im and Filipe
(2009), likewise in the present study, the micronutrient fertilizer Plonvit $\mathrm{R}$ had a beneficial effect on increasing oil content in rapeseed. In the opinion of $\mathrm{P} \mathrm{a} \mathrm{k}$ a et al. (2003), oil and protein yield per unit area is significantly dependent on the type of foliar fertilizers applied. For example, after the application of Mikrosol R oil yield was significantly higher compared to other fertilizers (Agrosol R, Plonvit R), but at the same time protein content was the lowest. On the other hand, in the opinion of the above-cited authors foliar fertilization slightly differentiates the basic chemical composition (oil, protein, fibre, ash, nitrogen-free extracts (NFE)) of rapeseed, which is modified more strongly by the cultivar factor. The technological value of rapeseed is largely dependent on the oil contained in it. This component is extracted or pressed in order to obtain raw oil, whereas protein and other ingredients become part of rapeseed extraction meal and determine its value (T y s et al. 2006).

Glucosinolates (glucose compounds with sulphur compounds) are found in Brassica plants (e.g. cauliflower, cabbage, broccoli, and oilseed rape). Alkenyl glucosinolates are considered to be harmful, since they may adversely affect the thyroid gland and even damage other organs (F e n wick et al. 1983). The glucosinolate content in rapeseed should be low, below 15 micromoles per gram of seed. In the present experiment, irrespective of the experimental treatment, the glucosinolate content in winter rapeseed ranged 10.1-12.6 micromoles per gram of seed.

At the same time, it should be added that, in addition to antinutritional properties, glucosinolate breakdown products also show protective (antitumor) activity for higher animals and humans (Trocz y ń s k a , 2005).

Table 1.

Winter survival of winter rape plants (crop loss in \%) - mean for 2009-2011

\begin{tabular}{|c|c|c|c|c|c|c|}
\hline \multirow{2}{*}{ Seeding rate $\mathrm{kg} \times \mathrm{ha}^{-1}$} & \multicolumn{6}{|c|}{ Fertilization* } \\
\hline & $\mathrm{A}^{*}$ & $\mathrm{~B}$ & $\mathrm{C}$ & $\mathrm{D}$ & $\mathrm{E}$ & Mean \\
\hline 4.0 & 10.4 & 6.4 & 9.0 & 4.6 & 4.9 & 7.1 \\
\hline 2.5 & 10.9 & 6.9 & 9.2 & 5.1 & 5.7 & 7.6 \\
\hline Mean & 10.6 & 6.6 & 9.1 & 4.8 & 5.3 & - \\
\hline \multicolumn{7}{|l|}{$\begin{array}{l}\text { LSD }_{0.05} \text { for: } \\
\text { fertilization }(a)=3.94 \\
\text { seeding rate }(b)=\text { n.s. } \\
\text { interaction }(a \times b)=\text { n.s. }\end{array}$} \\
\hline \multicolumn{7}{|c|}{$\begin{array}{l}\text { Explanation: } \\
\text { A - } 100 \% \text { of the NPK rate, without foliar fertilization (control treatment); } \\
\text { B }-100 \% \text { of the NPK rate and autumn spraying with the solution: urea + nickel chelate }+\mathrm{MgSO}_{4} \mathrm{H}_{2} \mathrm{O} \text {; } \\
\mathrm{C}-75 \% \text { of the NPK rate and autumn spraying with the solution: urea + nickel chelate }+\mathrm{MgSO}_{4} \mathrm{H}_{2} \mathrm{O} \\
\text { D }-100 \% \text { of the NPK rate and autumn spraying with the solution: urea + Plonvit } \mathrm{R}+\mathrm{MgSO}_{4} \mathrm{H}_{2} \mathrm{O} \\
\text { E }-75 \% \text { of the NPK rate and autumn spraying with the solution: urea + Plonvit } \mathrm{R}+\mathrm{MgSO}_{4} \mathrm{H}_{2} \mathrm{O} \text {. }\end{array}$} \\
\hline
\end{tabular}


Table 2.

Winter rape lodging in a 9-point scale - mean for 2009-2011

\begin{tabular}{cccccccc}
\hline \multirow{2}{*}{ Seeding rate $\mathrm{kg} \times \mathrm{ha}^{-1}$} & \multicolumn{5}{c}{ Fertilization* } \\
\cline { 2 - 7 } & $\mathrm{A}^{*}$ & $\mathrm{~B}$ & $\mathrm{C}$ & $\mathrm{D}$ & $\mathrm{E}$ & Mean \\
\hline 4.0 & 8.3 & 7.1 & 7.5 & 7.0 & 7.3 & 7.4 \\
2.5 & 9.0 & 8.1 & 8.7 & 7.5 & 7.9 & 8.2 \\
\hline Mean & 8.6 & 7.6 & 8.1 & 7.2 & 7.6 & - \\
\hline
\end{tabular}

$\mathrm{LSD}_{0.05}$ for:

fertilization $(\mathrm{a})=0.76$

seeding rate $(b)=0,71$

interaction $(a \times b)=$ n.s.

*Explanation in Table 1

${ }^{* *} 1^{\circ}$ - complete lodging of the crop; $9^{\circ}-$ no lodging

Table 3.

Number of siliques per winter rape plant (in pcs.) - mean for 2009-2011

\begin{tabular}{cccccccc}
\hline \multirow{2}{*}{ Seeding rate $\mathrm{kg} \times \mathrm{ha}^{-1}$} & \multicolumn{5}{c}{ Fertilization* $^{*}$} \\
\cline { 2 - 7 } & $\mathrm{A}^{*}$ & $\mathrm{~B}$ & $\mathrm{C}$ & $\mathrm{D}$ & $\mathrm{E}$ & Mean \\
\hline 4.0 & 126 & 145 & 151 & 137 & 131 & 138 \\
2.5 & 122 & 139 & 142 & 133 & 135 & 134 \\
\hline Mean & 124 & 142 & 146 & 135 & 133 & - \\
\hline
\end{tabular}

$\mathrm{LSD}_{0.05}$ for:

fertilization $(\mathrm{a})=13.8$

seeding rate $(b)=n . s$.

interaction $(\mathrm{a} \times \mathrm{b})=$ n.s.

*Explanation in Table 1

Table 4.

Number of seeds per silique on the main stem of winter rape (in pcs.) - mean for 2009-2011

\begin{tabular}{ccccccc}
\hline \multirow{2}{*}{ Seeding rate ${\mathrm{kg} \times \mathrm{ha}^{-1}}^{-1}$} & \multicolumn{5}{c}{ Fertilization* } \\
\cline { 2 - 7 } & $\mathrm{A}^{*}$ & $\mathrm{~B}$ & $\mathrm{C}$ & $\mathrm{D}$ & $\mathrm{E}$ & Mean \\
\hline 4.0 & 16.9 & 19.6 & 19.1 & 18.7 & 18.2 & 18.5 \\
2.5 & 16.4 & 18.2 & 18.4 & 18.0 & 17.8 & 17.7 \\
\hline Mean & 16.6 & 18.9 & 18.7 & 18.3 & 18.0 & - \\
\hline
\end{tabular}

$\mathrm{LSD}_{0.05}$ for:

fertilization $(\mathrm{a})=1.66$

seeding rate $(b)=n$.s.

interaction $(\mathrm{a} \times \mathrm{b})=$ n.s.

"Explanation in Table 1

Table 5.

Number of seeds per silique on the axillary branch of winter rape (in pcs.) - mean for 2009-2011

\begin{tabular}{ccccccc}
\hline \multirow{2}{*}{ Seeding rate ${\mathrm{kg} \times \mathrm{ha}^{-1}}^{-1}$} & \multicolumn{4}{c}{ Fertilization* } \\
\cline { 2 - 7 } & $\mathrm{A}^{*}$ & $\mathrm{~B}$ & $\mathrm{C}$ & $\mathrm{D}$ & $\mathrm{E}$ & Mean \\
\hline 4.0 & 9.4 & 12.9 & 13.2 & 12.0 & 12.2 & 12.0 \\
2.5 & 9.8 & 13.3 & 13.5 & 12.4 & 12.7 & 12.4 \\
\hline Mean & 9.6 & 13.1 & 13.3 & 12.2 & 12.4 & - \\
\hline
\end{tabular}

$\mathrm{LSD}_{0.05}$ for:

fertilization $(\mathrm{a})=1.51$

seeding rate $(b)=$ n.s.

interaction $(\mathrm{a} \times \mathrm{b})=\mathrm{n} . \mathrm{s}$.

*Explanation in Table 1 
Table 6.

1000 seed weight of winter rape (in g) - mean for 2009-2011

\begin{tabular}{|c|c|c|c|c|c|c|}
\hline \multirow{2}{*}{ Seeding rate $\mathrm{kg} \times \mathrm{ha}^{-1}$} & \multicolumn{6}{|c|}{ Fertilization* } \\
\hline & $\mathrm{A}^{*}$ & B & $\mathrm{C}$ & $\mathrm{D}$ & $\mathrm{E}$ & Mean \\
\hline 4.0 & 4.58 & 4.79 & 4.75 & 4.71 & 4.70 & 4.71 \\
\hline 2.5 & 4.64 & 4.82 & 4.80 & 4.73 & 4.75 & 4.75 \\
\hline Mean & 4.61 & 4.80 & 4.77 & 4.72 & 4.72 & - \\
\hline $\begin{array}{l}\text { LSD }_{0.05} \text { for: } \\
\text { fertilization }(a)=0.187 \\
\text { seeding rate }(b)=\text { n.s. } \\
\text { interaction }(a \times b)=\text { n.s. }\end{array}$ & & & & & & \\
\hline
\end{tabular}

Table 7.

Winter rapeseed yield $\left(\mathrm{t} \times \mathrm{ha}^{-1}\right)$ - mean for 2009-2011

\begin{tabular}{|c|c|c|c|c|c|c|}
\hline \multirow{2}{*}{ Seeding rate $\mathrm{kg} \times \mathrm{ha}^{-1}$} & \multicolumn{6}{|c|}{ Fertilization* } \\
\hline & $\mathrm{A}^{*}$ & $\mathrm{~B}$ & $\mathrm{C}$ & $\mathrm{D}$ & $\mathrm{E}$ & Mean \\
\hline 4.0 & 3.37 & 3.86 & 3.91 & 3.57 & 3.49 & 3.64 \\
\hline 2.5 & 3.25 & 3.68 & 3.79 & 3.50 & 3.54 & 3.55 \\
\hline Mean & 3.31 & 3.77 & 3.85 & 3.53 & 3.51 & - \\
\hline $\begin{array}{l}\text { LSD }_{0.05} \text { for: } \\
\text { fertilization }(a)=0.356 \\
\text { seeding rate }(b)=\text { n.s. } \\
\text { interaction }(a \times b)=\text { n.s. }\end{array}$ & & & & & & \\
\hline
\end{tabular}

Table 8.

Oil content in winter rapeseed $(\%)$ - mean for 2009-2011

\begin{tabular}{|c|c|c|c|c|c|c|}
\hline \multirow{2}{*}{ Seeding rate $\mathrm{kg} \times \mathrm{ha}^{-1}$} & \multicolumn{6}{|c|}{ Fertilization* } \\
\hline & $\mathrm{A}^{*}$ & B & $\mathrm{C}$ & $\mathrm{D}$ & $\mathrm{E}$ & Mean \\
\hline 4.0 & 41.4 & 43.2 & 43.3 & 44.0 & 44.3 & 43.2 \\
\hline 2.5 & 41.7 & 43.2 & 43.5 & 44.3 & 44.7 & 43.5 \\
\hline Mean & 41.6 & 43.2 & 43.4 & 44.1 & 44.5 & - \\
\hline $\begin{array}{l}\mathrm{LSD}_{0.05} \text { for: } \\
\text { fertilization }(\mathrm{a})=2.87 \\
\text { seeding rate }(\mathrm{b})=\text { n.s. } \\
\text { interaction }(\mathrm{a} \times \mathrm{b})=\text { n.s. }\end{array}$ & & & & & & \\
\hline
\end{tabular}

Table 9.

Protein content in winter rapeseed $(\%)$ - mean for 2009-2011

\begin{tabular}{|c|c|c|c|c|c|c|}
\hline \multirow{2}{*}{ Seeding rate $\mathrm{kg} \times \mathrm{ha}^{-1}$} & \multicolumn{6}{|c|}{ Fertilization* } \\
\hline & $\mathrm{A}^{*}$ & $\mathrm{~B}$ & $\mathrm{C}$ & $\mathrm{D}$ & $\mathrm{E}$ & Mean \\
\hline 4.0 & 22.2 & 22.5 & 22.4 & 22.6 & 22.5 & 22.4 \\
\hline 2.5 & 22.2 & 22.6 & 22.4 & 22.6 & 22.4 & 22.5 \\
\hline Mean & 22.2 & 22.6 & 22.4 & 22.6 & 22.4 & - \\
\hline $\begin{array}{l}\mathrm{LSD}_{0.05} \text { for: } \\
\text { fertilization }(\mathrm{a})=\text { n.s. } \\
\text { seeding rate }(\mathrm{b})=\text { n.s. } \\
\text { interaction }(\mathrm{a} \times \mathrm{b})=\text { n.s. }\end{array}$ & & & & & & \\
\hline
\end{tabular}

*Explanation in Table 1 
Table 10.

Glucosinolate content in winter rapeseed $\left(\mathrm{mmol} \times \mathrm{kg}^{-1}\right)$, irrespective of the seeding rate - mean for 2009-2011

\begin{tabular}{ccccccc}
\hline \multirow{2}{*}{ Glucosinolates } & \multicolumn{5}{c}{ Fertilization* } \\
\cline { 2 - 7 } & $\mathrm{A}^{*}$ & $\mathrm{~B}$ & $\mathrm{C}$ & $\mathrm{D}$ & $\mathrm{E}^{2}$ & LSD $_{0.05}$ \\
\hline Alkenyl (subtotal) & 6.1 & 5.8 & 5.3 & 6.7 & 7.0 & 0.62 \\
Indolic (subtotal) & 5.8 & 4.9 & 4.8 & 5.9 & 5.2 & 0.69 \\
Total (I + II) & 11.9 & 10.7 & 10.1 & 12.6 & 12.2 & 1.39 \\
\hline
\end{tabular}

*Explanation in Table 1

\section{CONCLUSIONS}

1. Foliar fertilizers (urea, magnesium sulphate monohydrate, nickel chelate, Plonvit R) contributed to improved winter hardiness and increased productivity of winter oilseed rape, but they had a lower effect on the chemical composition of rapeseed.

2. If foliar fertilizers are applied once during the autumn period, it seems justified to reduce the rates of soil-applied mineral NPK fertilizers by $1 / 4$.

3. The application of the lower seeding rate ( 40 plants per $1 \mathrm{~m}^{2}$ ) of the winter rape hybrid cultivar 'Kronos' is justified from the production point of view, since plant winter hardiness, seed yield as well as oil content and yield proved to be comparable with the parameters found when plant density was 70 plants per $1 \mathrm{~m}^{2}$.

4. Among the foliar fertilization treatments applied, the fertilizer combination: $75 \%$ of the NPK rate and autumn spraying with the solution: urea $(30 \mathrm{~kg} \mathrm{~N} \times /$ ha $\left.^{-1}\right)+$ nickel chelate $\left(2 \mathrm{dm}^{3} \times \mathrm{ha}^{-1}\right)+\mathrm{MgSO}_{4} \mathrm{H}_{2} \mathrm{O}$ $\left(7.5 \mathrm{~kg} \times \mathrm{ha}^{-1}\right)$, had the most beneficial effect on winter rape yield and produced the lowest glucosinolate content. The effect of the action of such a combination of foliar fertilizers was similar in the case of both seeding rates.

\section{Acknowledgements}

Research supported by Poland's Ministry of Science and Higher Education as part of the statutory activities of the Department of Herbology and Plant Cultivation Techniques, University of Life Sciences in Lublin.

\section{REFERENCES}

Barłóg P., Potarzycki J., 2000. Plonotwórcza i ekonomiczna efektywność magnezu zastosowanego dolistnie w uprawie rzepaku ozimego. / The yield-increasing and economic effectiveness of foliar-applied magnesium in winter oilseed rape crops. [In:] Zbilansowane nawożenie rzepaku. Aktualne problemy, W. Grzebisz (ed.): 151-156. (in Polish)

B u d z y ńs k i W ., 2006. Efektywność wybranych czynników produkcji. [In:] Rzepak, wyd. II G. Milewski (ed.). Wydawnictwo Biznes-Press sp. z o.o.: 34-40. (in Polish)
Brzozowska I., Brzozowski J., Hruszka M., 2008. Plonowanie i struktura plonu pszenicy ozimej w zależności od sposobu pielęgnacji i nawożenia azotem. / Yielding and yield structure of winter wheat in dependence on methods of crop cultivation and nitrogen fertilisation. Acta Agrophys. 11(3): 597-611. (in Polish)

Chrzanowska-Drożdż B., 2001. Reakcja pszenicy ozimej na dawki i terminy stosowania azotu. Część I. Rozwój i plonowanie pszenicy ozimej w zależności od dawki i terminu stosowania azotu. / Response of winter wheat on rates and dates of nitrogen application. Part I. Development and yielding of winter wheat depending on time and nitrogen rates. Zesz. Nauk. AR Wroc. 415, Rol. 80, 257-281. (in Polish)

Czuba R., Sztuder H., Świerczewska M., 1995. Dolistne dokarmianie rzepaku ozimego i gorczycy białej azotem, magnezem i mikroelementami. / Foliar fertilization of winter oilseed rape and white mustard with nitrogen, magnesium and microelements. Wydawnictwo IUNG Puławy, P (58), 26. (in Polish)

Fenwick G.R., Heaney R.K. Mullin W.J., 1983. Glucosinolates and their breakdown products in food and food plants. Crit. Rev. Food Sci. Nutr. 18: 123-201.

Fig a s A., 2009. Wpływ sposobu nawożenia siarką i dolistnej aplikacji magnezu i boru na plonowanie rzepaku jarego oraz zawartość glukozynolanów w nasionach. / Influence of sulphur fertilization and foliar application of magnesium and boron on spring oilseed rape yield and glucosinolate content in seeds. Fragm. Agron. 26 (1): 25-33. (in Polish)

Gerendás J., Sat tel macher B., 1997. Significance of $\mathrm{Ni}$ supply for growth, urease activity and the concentrations of urea, amino acids and mineral nutrients of urea-grown plants. Plant Soil, 190: 153-162.

Haras i m P., Filipek T., 2009. Wpływ dokarmiania dolistnego mocznikiem, niklem i innymi mikroelementami na plon nasion oraz zawartość tłuszczu i glukozynolanów w rzepaku jarym / Effect of foliar fertilization with urea, nickel and other microelements on seed yield as well as fat and glucosinolate content in spring oilseed rape. Zesz. Probl. Post. Nauk Roln. 542 (1): 177-183. (in Polish)

Jaskulski D., 2004. Efektywność dolistnego stosowania nawozów „Sonata”. / Effectiveness of foliar application of "Sonata" fertilizers. Ann. UMCS, Sect. E, 59 (1): 431-439. (in Polish) 
Korbitz W., 2003. New trends in developing biodiesel worldwide. $11^{\text {th }}$ Int. Rapeseed Congr. 2: 603-607.

Lista Opisowa Odmian. 2009. Rośliny rolnicze cz. 2. COBORU Słupia Wielka: 5-22. (in Polish)

Mahler R.L., 2004. General overview of nutrition for field and container crops. USDA Forest Service Proc. RMRS-P-33: 26-29.

Marku s J., 1999. Wpływ nawożenia mineralnego na jakość rzepaku ozimego i jarego. / Effect of mineral fertilization on the quality of winter and spring oilseed rape. [In:] Środowiskowe i agrotechniczne uwarunkowania jakości płodów rolnych. SGGW Warszawa: 36 (in Polish)

Now orolnik K., 1996. Reakcja odmian i rodów jęczmienia jarego na poziom nawożenia azotem. / Response of spring barley cultivars to nitrogen fertilization level. Biul. IHAR 197: 121-125. (in Polish)

$\mathrm{P}$ a is L., 1983. The biological importance of titanium. J. Plant Nutr. 6: 3-131.

Pałka M., Bobrecka-Jamro D., Jarecki W., 2003. Wpływ wieloskładnikowych nawozów dolistnych na skład chemiczny nasion oraz wydajność tłuszczu i białka rzepaku jarego / Influence of compound foliar fertilizers on the chemical composition of seeds as well as fat and protein productivity of spring rape. Acta Agrophys. 85: 277-287. (in Polish)

Sienkiewicz-Cholewa W., Gembarzewski M., 1997. Badania nad potrzebami podwójnie ulepszonych odmian rzepaku ozimego. Wyd. IUNG Puławy, S (81): 36. (in Polish)

Skrzypczak G., 2006. Odchwaszczanie rzepaku ozimego. [In:] Rzepak, wyd. II Milewski G. (ed.). Wydawnictwo Biznes-Press sp. z 0.o.: 84-86. (in Polish)

Szewczuk C., 2003. Wpływ stosowania wybranych nawozów dolistnych na przezimowanie i plony nasion rzepaku ozimego / Effect of application of chosen foliar fertilizers on winter hardiness and seed yields of winter rape. Acta Agrophys. 85: 289-295. (in Polish)

Szulc P.M., Drozdowska L., Kachlicki P., 2003. Effect of sulphur on the yield and content of glucosinolates in spring oilseed rape seeds. EJPAU 6 (2): art.0.1.html.

Troczy ń s k a J ., 2005. System mirozynaza - glukozynolany - charakterystyka i funkcje w roślinie. / System myrosinase - glucosinolates - its character and functions in plant. Rośliny Oleiste - Oilseed Crops, 26 (1): 51-64. (in Polish)

Tys J., Jackowska I., Rybacki R., 2006. Wartość technologiczna nasion różnych odmian rzepaku ozimego przeznaczonych na biopaliwa. / Technological value of different varieties of winter rapeseed developed for bio-diesel. Acta Agrophys. 8 (4): 1017-1030. (in Polish)

Wałkowski T., 2001. Wpływ terminu i gęstości wysiewu na plony rzepaku jarego odmiany populacyjnej Star i mieszańca złożonego Margo. / Influence of sowing date and sowing rate on the yields of spring rapeseed varieties: open pollinated variety Star and composite hybryd Margo. Rośl. Oleiste - Oilseed Crops, 22 (2): 409-414. (in Polish)

\section{Reakcja rzepaku ozimego \\ (Brassica napus L. ssp. oleifera Metz., Sinsk) na nawożenie dolistne i zróżnicowaną gęstość siewu}

\section{Streszczenie}

Eksperyment polowy z uprawą rzepaku ozimego przeprowadzono w latach 2009-2011 w gospodarstwie rodzinnym (M. Bednarczyk) w Jaroszewicach (woj. lubelskie), na glebie bielicowej. Oceniano cechy biometryczne rośliny, plonowanie i parametry jakościowe nasion (zawartość tłuszczu, białka, glukozynolanów) w zależności od dawki nawożenia doglebowego NPK i dolistnego (oprysk jesienny roztworem): $100 \%$ i $75 \%$ NPK oraz mocznik + chelat niklu $+\mathrm{MgSO}_{4} \mathrm{H}_{2} \mathrm{O} ; 100 \%$ i $75 \%$ NPK oraz mocznik + Plonvit $\mathrm{R}+\mathrm{MgSO}_{4} \mathrm{H}_{2} \mathrm{O}$ ). Obiekt kontrolny stanowiły poletka bez nawożenia dolistnego (wyłącznie $100 \%$ NPK). Drugim czynnikiem była gęstość siewu nasion $\left(2,5{\mathrm{~kg} \times \mathrm{ha}^{-1}}^{-}\right.$rozstawa rzędów $30 \mathrm{~cm}$; $4 \mathrm{~kg} \times \mathrm{ha}^{-1}$ - rozstawa rzędów $18 \mathrm{~cm}$ ). Opryski dolistne przeprowadzano jednorazowo jesienią $\mathrm{w}$ drugiej dekadzie października.

Uprawa roli oraz mechaniczno-chemiczna ochrona plantacji przed agrofagami były typowe dla gatunku rośliny i zgodne z zaleceniami dotyczącymi ochrony rzepaku ozimego.

Przyjęto hipotezę, że zastosowanie nawozów dolistnych wpłynie korzystnie na produkcyjność rzepaku ozimego, z jednoczesnym zachowaniem wysokiej jakości surowca. Założono również, że zmniejszenie gęstości wysiewu nasion rzepaku ozimego wpłynie na ograniczenie wylegania roślin, zwiększenie liczby łuszczyn na roślinie, a w konsekwencji osiąganie produkcyjności nasion i tłuszczu na poziomie nie mniejszym, aniżeli uzyskanym w warunkach większej ilości wysiewu nasion.

Udowodniono, że dolistne dokarmianie rzepaku ozimego w okresie jesiennym przyczynia się do poprawy zimotrwałości roślin i zwiększenia produkcyjności. Zastosowanie nawozów dolistnych umożliwia także ograniczenie dawek podstawowych nawozów mineralnych NPK o $25 \%$, bez szkody dla wielkości plonu nasion. Stwierdzono słabsze oddziaływanie nawozów dolistnych na zmianę składu chemicznego nasion rzepaku. Wykazano, iż z punktu widzenia produkcyjnego uzasadnione jest stosowanie mniejszej gęstości siewu

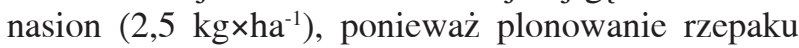
ozimego (plon nasion i tłuszczu) nie odbiegały istotnie od stwierdzonego w warunkach większej gęstości sie-

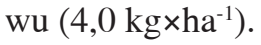

